\title{
Functional Anatomy of Incisal Biting in Aplodontia rufa and Sciuromorph Rodents - Part 1: Masticatory Muscles, Skull Shape and Digging
}

\author{
Robert E. Druzinsky \\ Departments of Occupational and Physical Therapy, Governors State University, University Park, III., USA
}

\author{
Key Words \\ Masticatory apparatus · Evolution • Rodent $\cdot$ Sciuromorph • \\ Protrogomorph
}

\begin{abstract}
Traditionally, rodents have been grouped into suborders distinguished largely on the basis of characteristics of the jaw adductor muscles and other features of the masticatory apparatus. The three classic suborders are: Sciuromorpha (squirrels), Myomorpha (rats and mice), and Hystricomorpha (porcupines and the South American caviomorph rodents). Protrogomorph rodents are thought to represent the primitive condition of rodent masticatory muscles. Aplodontia rufa, the mountain beaver, is the only living protrogomorphous rodent. The present work is a detailed comparison of the masticatory apparatus in A. rufa and Marmota monax, the woodchuck. But the mandibular region of $A$. rufa appears remarkable, unlike anything found in other rodents. Is A. rufa a reasonable representative of the primitive, protrogomorphous condition? A. rufa is a member of the aplodontoid-sciuroid clade with a wide and flat skull. The large temporalis and mandibular apophyses of $A$. rufa are features re-
\end{abstract}

Druzinsky, R.E. (2010) Functional anatomy of incisal biting in Aplodontia rufa and sciuromorph rodents. - Part 2: Sciuromorphy is efficacious for production of force at the incisors. Cells Tissues Organs 192: 50-63. DOI: $10.1159 / 000284930$.

\section{KARGER}

Fax +4161306 1234

E-Mail karger@karger.ch

www.karger.com (c) 2010 S. Karger AG, Basel

Accessible online at: www.karger.com/cto lated to its relatively wide skull. Such features are found in less dramatic forms in other sciuromorphous species and the basic arrangement of the masticatory muscles of $A$. rufa is similar to the arrangement seen in sciuromorphs.

Copyright $\odot 2010$ S. Karger AG, Basel

\section{Introduction}

The uniqueness of the masticatory apparatus of rodents has been apparent to morphologists since the time of Linnaeus [1758; Brant, 1855]. Traditionally, the rodents have been grouped into suborders distinguished largely on the basis of characteristics of the jaw adductor muscles

\section{Abbreviations used in this paper}

ALM anterior lateral masseter

PI internal pterygoid

PLM posterior lateral masseter

PM posterior masseter

PZM posterior zygomaticomandibularis

SM superficial masseter

TA anterior temporalis

TP posterior temporalis

TZ suprazygomatic portion of the temporalis

ZM zygomaticomandibularis 
and other features of the masticatory apparatus. The three classic suborders are: Sciuromorpha (squirrels), Myomorpha (rats and mice), and Hystricomorpha (porcupines and the South American caviomorph rodents) [e.g., Wood, 1955]. Characteristics used to define the groups include differences in the position and architecture of the masseter and zygomaticomandibularis (ZM) muscles (see below for an explanation of the nomenclature). An additional, fourth suborder of rodents, Protrogomorpha, was defined by Wood [1937, p. 160]. Protrogomorpha are '... rodent families in which the masseter has not modified the form of the infra-orbital foramen in any manner .... Protrogomorph rodents are thought to represent the primitive condition of rodent masticatory muscles in that they lack the rostral expansions of the masseter and ZM found in all of the other extant sciuromorph, hystricomorph, and myomorph species. In their recent, comprehensive study of the Eurymylid Rhombomylus, Meng et al. [2003] found that Eurymylids are probably the sister group of the Rodentia, and their reconstruction of the masticatory muscles of Rhombomylus suggests that these were protrogomorphs as well.

Today, the Sciuromorpha, Hystricomorpha, and Myomorpha sensu stricto are not considered to be monophyletic groups [Wood, 1965], and it is clear that each of these major grades of the rodent masticatory apparatus may have evolved more than once. Two suborders of rodents (Sciurognathi and Hystricognathi) are sometimes recognized based on the morphology of the ventral border of the lower jaw [Tullberg, 1899; Landry, 1957, 1999; Lavocat, 1974; Wood, 1974]. Although the Hystricognathi may be monophyletic [Luckett and Hartenberger, 1985; Huchon et al., 2002; Meng et al., 2003], the anatomical conditions of hystricomorphy, myomorphy, and sciuromorphy have all evolved more than once [Lavocat, 1974; Wood, 1974; Luckett and Hartenberger, 1985; VianeyLiaud, 1985; Thorington and Darrow, 1996; Hartenberger, 1985; Nedbal et al., 1996; Huchon et al., 2000; Meng et al., 2003; Adkins et al., 2001].

Aplodontia rufa, the mountain beaver, is the only living protrogomorphous rodent [Anderson and Jones, 1984]. Although A. rufa is thought to be representative of the primitive, protrogomorph grade of rodent masticatory apparatus [Wood, 1965], most authors believe that the aplodontoid and sciuroid rodents form a clade within the Rodentia based on morphological [e.g., Simpson, 1945; Wahlert, 1985; Meng, 1990; Korth and Emry, 1991] and biochemical/molecular [Sarich, 1985; Huchon, et al., 1999, 2000; Adkins et al., 2001, 2003; Debry and Sagel, 2001; Huchon et al., 2002] analyses. A sister group rela- tionship between the Aplodontidae and Sciuridae (among the extant rodents) and placement of the Aplodontoidea within the Sciuromorpha [e.g., Korth and Emry, 1991; Landry, 1999] strongly suggest that the Protrogomorpha are a paraphyletic group.

The present work is a detailed comparison of the masticatory apparatus in A. rufa and Marmota monax. A. rufa is the only extant protrogomorph. M. monax represents sciuromorph anatomy, which is thought to be a derived 'elaboration' of the primitive rodent masticatory apparatus. But the mandibular region of $A$. rufa appears remarkable, unlike anything found in other rodents. Is A. rufa is a reasonable representative of the primitive, protrogomorphous condition?

\section{Materials and Methods}

Five woodchucks (Marmota monax) and 8 mountain beavers (Aplodontia rufa) obtained for the study [Druzinsky, 1989, 1995] were dissected. Single specimens from 5 sciuromorphous species, from the collections of the Field Museum of Natural History, Chicago, Ill., were also dissected (table 1) for comparisons. Animals were dissected with the aid of a dissecting microscope using standard anatomical techniques. Muscles were blotted dry, large tendons and connective tissues removed, and the muscles were weighed. After weighing, muscles were dissected in weak nitric acid to measure fascicle lengths.

\section{Jaw Adductor Muscle Nomenclature}

With a major exception, i.e. the muscle that originates from the medial wall of the zygomatic arch is called the ZM, the naming scheme employed by Woods and Howland [1979] for hystricomorphs will be followed; however, English names will be used. Woods and Howland called this muscle the 'masseter medialis', as have many other specialists of the Rodentia [e.g., Tullberg, 1899; Satoh and Iwaku, 2004, 2006]. This name is rarely, if ever, used in other groups of mammals. In other mammals, the medial masseter of rodents is usually called the 'ZM' or the deep masseter muscle [e.g., DuBrul, 1980; Fish, 1983]. To simplify comparisons between rodents and other mammals, ' $\mathrm{ZM}$ ' will be used in the present study. Comparative anatomists have used this term for many years [e.g., Parsons, 1894; Von Toldt, 1905; Stark and Wehrli, 1935; Becht, 1953; Turnbull, 1970; Offermans and de Vree, 1989; Ball and Roth, 1995; Thorington and Darrow, 1996].

Since the ZM is usually called the 'deep masseter' in humans and other primates, the use of the term 'deep masseter' [Ball and Roth, 1995; Thorington and Darrow, 1996] for fibers that originate on the lateral surface and ventral border of the zygomatic arch is confusing, so this muscle will be called the 'lateral masseter' following Woods and Howland [1979; Tullberg, 1899].

In hystricomorph rodents, a distinct muscle that originates from the lateral jugal fossa [Woods and Howland, 1979] on the posterior part of the jugal has been called the ' $m$. masseter lateralis profundus, pars posterior, deep division' [Woods, 1972] and, later, the ' $m$. masseter posterior' [Woods and Howland, 1979]. In recent studies of A. rufa and sciuromorphs [Ball and Roth, 1995; 
Table 1. Museum specimens used in the study

\begin{tabular}{|c|c|c|c|}
\hline Species & ID No. & Sex & Material \\
\hline Aplodontia rufa rufa & FMNH41388 & M & dried skull \\
\hline Aplodontia rufa pacifica & FMNH9051 & M & dried skull \\
\hline Aplodontia rufa pacifica & FMNH9048 & $\mathrm{F}$ & dried skull \\
\hline Aplodontia rufa pacifica & FMNH9072 & $\mathrm{F}$ & dried skull \\
\hline Aplodontia rufa olympica & FMNH6313 & M & dried skull \\
\hline Aplodontia rufa; rufa & AMNH127292 & M & dried skull \\
\hline Aplodontia rufa California & AMNH1297 & M & dried skull \\
\hline Aplodontia rufa pacifica & AMNH38235 & M & dried skull \\
\hline Aplodontia rufa pacifica & AMNH36879 & M & dried skull \\
\hline Cynomys ludovicianus & FMNH126631 & $?$ & in alcohol \\
\hline Cynomys ludovicianus & FMNH122616 & $\mathrm{F}$ & dried skull \\
\hline Cynomys ludovicianus & FMNH50812 & $\mathrm{F}$ & dried skull \\
\hline Cynomys ludovicianus & FMNH5449 & M & dried skull \\
\hline Cynomys cynomys gunnisoni & AMNH131853 & M & dried skull \\
\hline Tamias minimus operarius & FMNH123533 & M & in alcohol \\
\hline Tamias minimus minimus & FMNH4833 & $\mathrm{F}$ & dried skull \\
\hline Tamias minimus minimus & FMNH4829 & $\mathrm{F}$ & dried skull \\
\hline Tamias minimus operarius & FMNH77047 & M & dried skull \\
\hline Geomys bursarius & FMNH123435 & M & dried skull \\
\hline Marmota monax monax & FMNH457 & $?$ & dried skull \\
\hline Marmota monax bunkeri & AMNH142643 & $\mathrm{F}$ & dried skull \\
\hline Marmota monax preblorum & AMNH169915 & M & dried skull \\
\hline Marmota monax preblorum & AMNH169928 & M & dried skull \\
\hline Marmota monax preblorum & AMNH169899 & M & dried skull \\
\hline Marmota monax preblorum & AMNH185178 & $\mathrm{F}$ & dried skull \\
\hline Marmota monax preblorum & AMNH169842 & M & dried skull \\
\hline Marmota monax rufescens & AMNH13927 & $\mathrm{F}$ & dried skull \\
\hline Marmota monax rufescens & AMNH122676 & M & dried skull \\
\hline Marmota monax rufescens & AMNH3511 & M & dried skull \\
\hline Ratufa affinis & FMNH68749 & $\mathrm{F}$ & in alcohol \\
\hline Ratufa affinis sandakanensis & FMNH85937 & M & dried skull \\
\hline Ratufa affinis sandakanensis & FMNH85938 & M & dried skull \\
\hline Ratufa affinis & FMNH43359 & M & dried skull \\
\hline Ratufa affinis sandakanensis & FMNH85940 & M & dried skull \\
\hline Sciurus variagatoides & FMNH126077 & $?$ & in alcohol \\
\hline Sciurus variagatoides melania & FMNH14247 & $\mathrm{F}$ & dried skull \\
\hline Sciurus variagatoides melania & FMNH14246 & $\mathrm{F}$ & dried skull \\
\hline Sciurus variagatoides melania & FMNH14253 & $\mathrm{F}$ & dried skull \\
\hline Sciurus variagatoides goldmani & FMNH77320 & $\mathrm{M}$ & dried skull \\
\hline Sciurus carolinensis pennsylvanicus & AMNH183128 & M & dried skull \\
\hline Thomomys talpoides fuscus & FMNH126162 & $?$ & in alcohol \\
\hline Thomomys talpoides fuscus & FMNH18266 & M & dried skull \\
\hline Thomomys talpoides fuscus & FMNH18267 & M & dried skull \\
\hline Thomomys talpoides fuscus & FMNH18265 & $\mathrm{F}$ & dried skull \\
\hline Thomomys talpoides columbianus & FMNH53887 & $\mathrm{F}$ & dried skull \\
\hline
\end{tabular}

Thorington and Darrow, 1996], there are no indications that the authors made a distinction between posterior fibers of the lateral masseter, ZM, and this third muscle, the posterior masseter (PM). Even though the orientation of the PM is very different in hystricomorphs compared to A. rufa and sciuromorphs, the positions of the origin and insertion are very similar. Thus, these fibers are called the 'PM' in the present study.
Other Osteological Measures

Bizygomatic breadth (maximum skull width across the zygomatic arches), minimum skull width, maximum skull height, and maximum mandibular height and width were measured with calipers. 


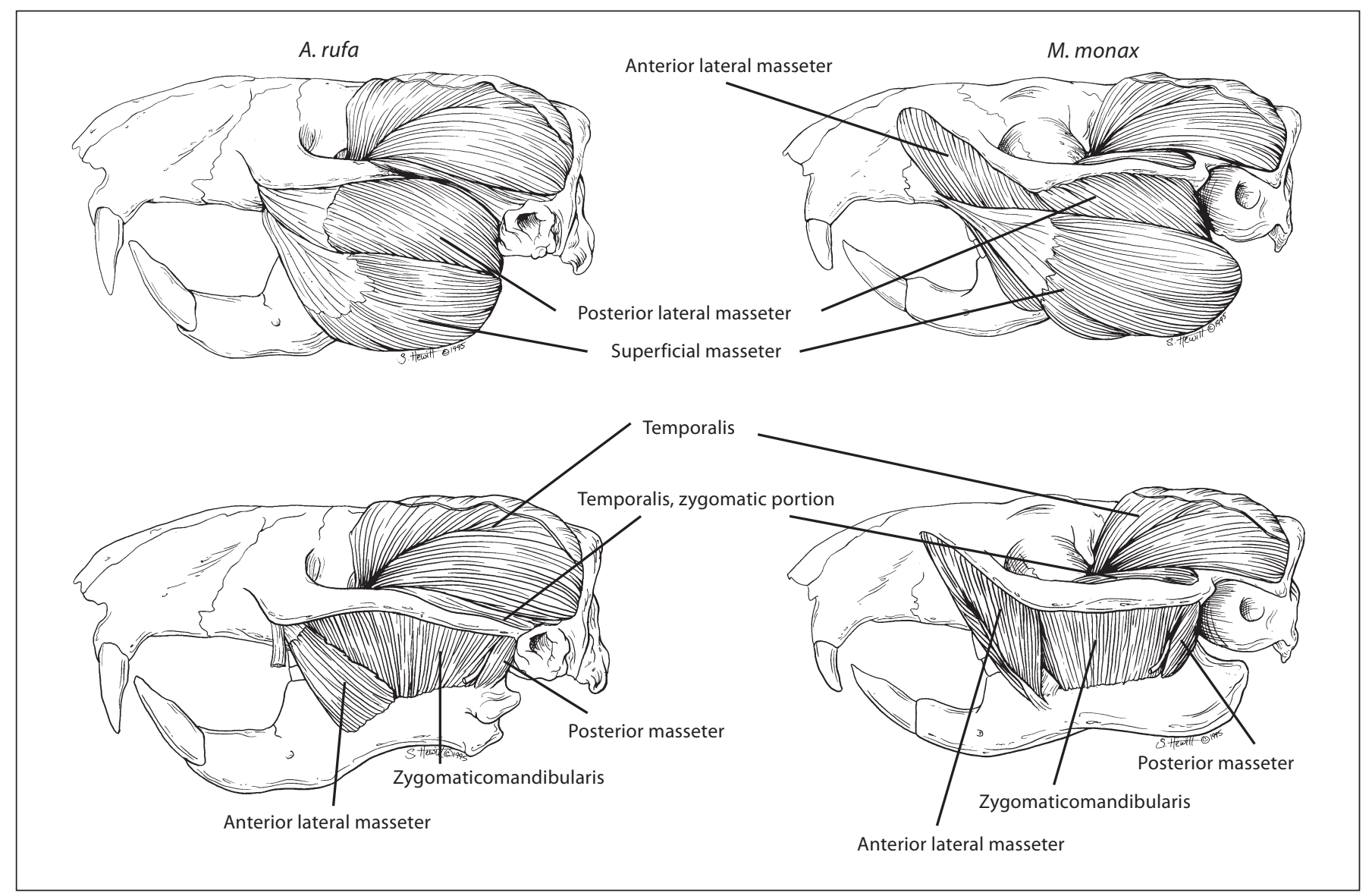

Fig. 1. Lateral views of the jaw adductor muscles of $A$. rufa and M. monax. Top: the superficial masseter muscle is intact. Bottom: the superficial masseter muscle has been removed.

\section{Results}

\section{Superficial Masseter}

In M. monax the superficial masseter (SM) originates from a large tubercle just lateral and ventral to the infraorbital foramen (fig. 1). The tendon broadens into a wide aponeurosis. Short fibers originate from the deep surface of the aponeurosis to insert on the mandible near the mandibular angle. The most dorsal fibers of the SM cannot be separated from fibers of the lateral masseter, pars posterior. Some fibers from the anteroventral edge of the SM wrap around the angle to insert on a broad plane on the ventral surface of the mandible (fig. 2). These fibers are similar (but not necessarily homologous) to the part of the masseter called the 'pars reflexa' [Schumacher, 1961] in other mammals.

The laterally projecting, pontoon-like apophyses on the mandible of $A$. rufa are associated with some unusu- al morphological feature of the adductor muscles. In fact, the patterns of origins and insertions of the adductor muscles are remarkably similar in the two species.

In $A$. rufa the SM arises as a thick, flattened tendon from a roughened, oval area of the ventral surface of the zygomatic arch below the infraorbital foramen (fig. 1). The tendon is roughly half a centimeter long in adults. At its distal end, the tendon becomes a hollow cone and muscle fibers originate from its inner as well as its outer walls. The fibers fan out from their origins on the tendon and run posteriorly and ventrally to insert on the horizontal portion of the mandible between the ventral edge of the angle and the most lateral edge of the pontoon (fig. 3). A small group of fibers that arise on the inferior surface of the tendon insert in a distinct fossa on the ventromedial surface of the mandible just anterior to the attachment of the medial pterygoid muscle. 
Fig. 2. Ventral views of $A$. rufa and $M$. monax depicting the superficial masseter muscles.

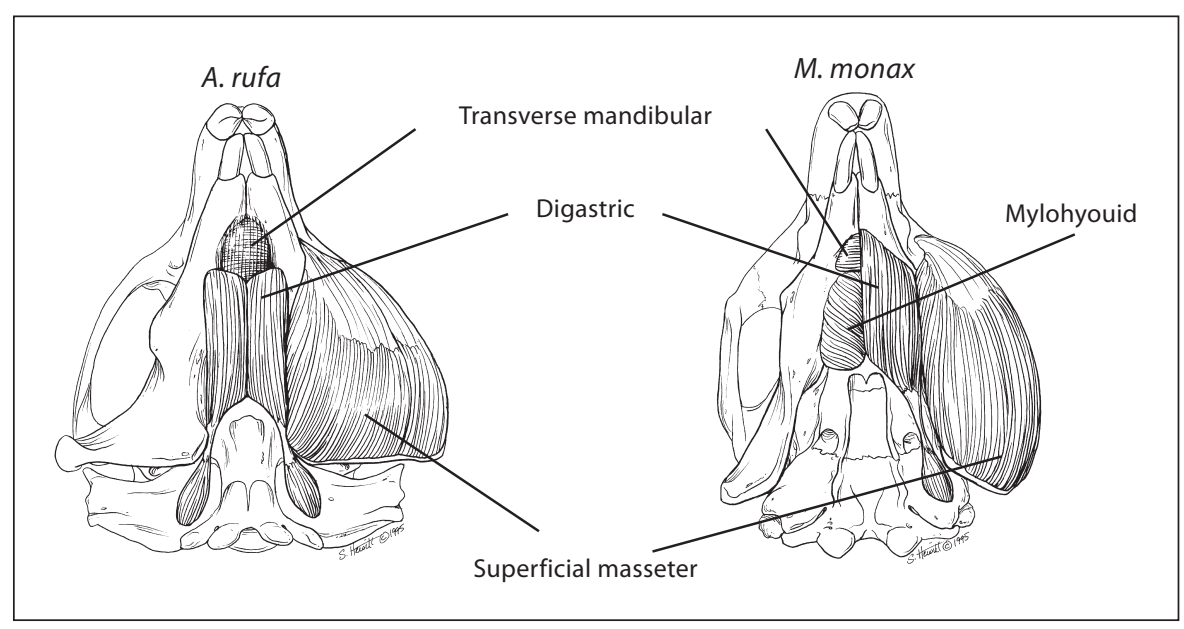

\section{Lateral Masseter}

The lateral masseter is clearly divisible into two distinct parts in both species, herein referred to as the anterior lateral masseter (ALM) and posterior lateral masseter (PLM). Each part will be described as a separate muscle.

\section{Anterior Lateral Masseter}

In M. monax, the ALM is a pinnate muscle. It is thickest at its anterior end, where it originates from the anteroventral surface of the root of the zygomatic arch (fig. 1). The muscle tapers to a thin sheet of fibers that originate from the medial surface of an aponeurosis that is attached to the ventral edge of the zygomatic arch. The fibers end in several short tendinous sheets which insert on the lateral surface of the mandible. At the anterior end of the insertion there is a tubercle for the attachment of a tendon. This anterior tendon arises from fibers that originate in the fossa anterior to the root of the zygomatic arch.

In A. rufa, the ALM is incompletely separable from the posterior portion of the next muscle to be described, the PLM. At its anterior end, the fibers originate from the ventral surface of the zygomatic arch just lateral to the origin of the SM. In this region, the origin is fleshy, but posteriorly the fibers originate from the medial side of a tendinous aponeurosis that is attached to the ventral edge of the zygomatic arch. This tendon is used to distinguish the ALM from the PLM. Muscle fibers that originate on the lateral surface of the tendon are (by definition herein) part of the PLM, and fibers that arise on the medial surface are part of the ALM. The ALM is a pinnate muscle, thick at its anterior end, tapering to a thin sheet at its pos-

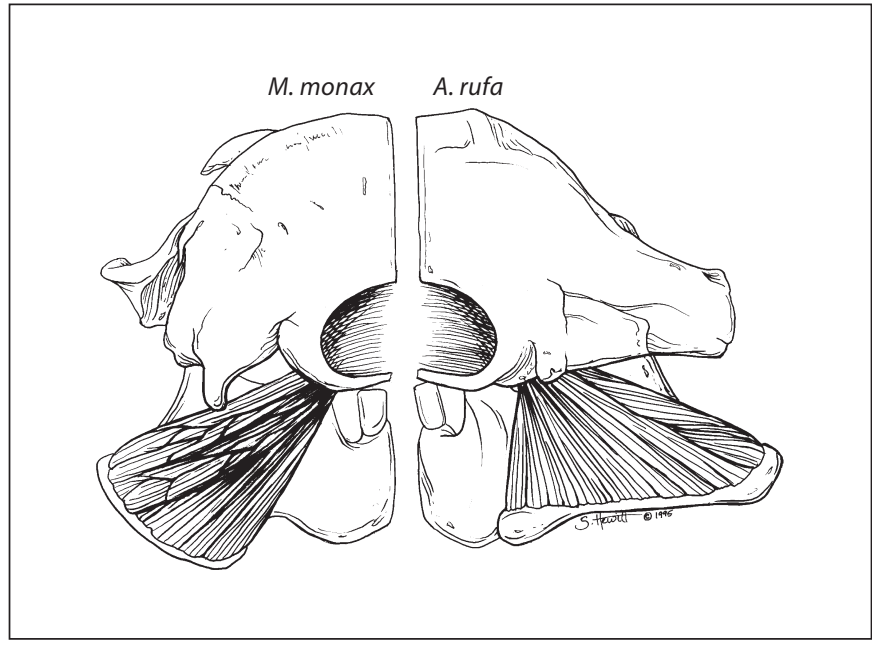

Fig. 3. Posterior views of A. rufa and M. monax depicting the internal pterygoid muscles.

terior end. The muscle fibers run ventrally and slightly posteriorly (fig. 1). The most anterior fibers insert at the anterior end of the masseteric line on the lateral surface of the mandible. Posteriorly, the fibers blend with the fibers of the PLM.

\section{Posterior Lateral Masseter}

The PLM is almost a true unipinnate muscle. Most of the fibers extend from origin to insertion, parallel to most of the other fibers when the mouth is closed, but some of the fibers that originate from the anterior tendon run much more horizontally than the other fibers of the muscle. In M. monax, the PLM is inseparable from the 
ALM. It originates from the ventrolateral surface of the zygomatic arch and from the lateral surface of the tough origination tendon that attaches to the ventral border of the arch (fig. 1). The fibers of the PLM run posteriorly and ventrally to insert on several dense aponeuroses attached to the caudal edge of the mandibular ramus along the masseteric line.

In A. rufa, the PLM originates just posterior and lateral to the origin of the ALM (fig. 1). The PLM originates from the large lateral and ventrally facing surface, and the ventral edge, of the zygomatic arch. The most anterior fibers of the PLM originate from a thin tendon; a small tubercle often marks the origin of this tendon. The majority of the posterior fibers have a fleshy origin although the most medial fibers, as mentioned above, originate from the lateral surface of a thin tendinous sheet that they share with fibers of the ALM. The fibers run posteriorly and ventrally to insert on the lateral surface of the mandible anterior to the pontoon, and the anterior and dorsal surfaces of the pontoon itself. At its anteroventral border, the fibers of the PLM are incompletely separable from the fibers of the SM.

\section{Zygomaticomandibularis}

The origin of the ZM is from the medial surface of the zygomatic arch, the internal surface of the maxillary root of the zygomatic arch, and from a small area on the ventral surface of the posterior root of the zygomatic arch, just lateral to the glenoid fossa (fig. 1). In M. monax, the ZM is a thin fan of fibers that inserts, by means of fleshy fibers, near the base of the coronoid process. There are anterior and posterior thickenings of the ZM. The most anterior fibers insert onto a short tendon at the anterior root of the coronoid process. The posterior fibers are a horizontally oriented band that originates on the ventral surface of the posterior root of the zygomatic arch and runs anteriorly to join the fibers of the zygomatic portion of the temporalis. The posterior portion of the ZM (PZM) is probably homologous to the PZM or m. masseter medialis, pars posterior of other authors [cf., Tullberg, 1899; Von Toldt, 1905; Stark and Wehrli, 1935; Ball and Roth, 1995; Thorington and Darrow, 1996], but these authors may also have included all or part of what is called the PM in the present study.

In A. rufa, anterior and posterior thickenings of the $\mathrm{ZM}$ are more pronounced than in M. monax. Anterior fibers of the ZM run posteroventrally while the most posterior fibers run anteroventrally. The muscle is thickest at its anterior and posterior ends, and fills a fossa at the root of the zygomatic arch, posterior and lateral to the infra- orbital foramen. Coues [1877] and Eastman [1982] have reported fibers of the $\mathrm{ZM}$ that run through this foramen along with the infraorbital nerve and vessels, but no such fibers were found in the present investigation. In all of the animals dissected to date, a distinct plane of loose connective tissue separates the internal walls of the infraorbital foramen from the muscle, and fibers of the m. dilator nasi [Klingener, 1970] originate from the external edges of the foramen, completely covering its external opening, except for the path of the infraorbital vessels and nerve. Without very careful dissection with a dissecting microscope, fibers of the $\mathrm{m}$. dialator nasi appear to be fibers of the ZM that traverse the infraorbital foramen onto the snout.

The posterior part of the muscle (PZM) originates from a distinct, crescent-shaped fossa lateral to the glenoid fossa. Some of these posterior fibers are nearly horizontal in their orientation. Fibers of the ZM in A. rufa insert on the lateral surface of the mandible at the root of the coronoid process. At the anterior end of the insertion, the fibers insert onto a short, thin tendon. The rest of the insertion is fleshy. In some specimens, there is a very faint ridge that marks the ventral extent of the insertion of the $\mathrm{ZM}$ on the mandibular ramus anterior to the pontoon and inferior to the coronoid process.

\section{Posterior Masseter}

In $M$. monax, the PM is a small but distinct muscle that originates from a roughened area at the most posterior end of the ventral surface of the zygomatic arch (fig. 1). It inserts in a fossa just inferior to the mandibular notch, posterior and lateral to the insertion of the ZM. The fibers run parallel to one another in an anteroventral direction. The origins and insertions of the PM are almost entirely fleshy. The course of the masseteric nerve sometimes follows the plane that separates the ZM from the PM. The anatomy of the PM in A. rufa is almost identical to that of $M$. monax. But since the lateral bulge of the mandible is much more prominent in A. rufa than in M. monax, the fossa for the insertion of the PM is much more distinct than it is in $M$. monax.

The position of the PM in hystricomorphs is broadly similar to that of A. rufa and M. monax, with some interesting differences. In hystricomorphs, the fibers of the PM run posteriorly (caudally) and ventrally to insert below the condyle on the ascending ramus and the postcondyloid process. In A. rufa and M. monax, they run anteriorly and ventrally from their origin to insert in a distinct fossa on the ascending ramus. 


\section{Temporalis}

In M. monax, the temporalis originates from the dorsal surface of the skull, the dorsal surface of the zygomatic arch, and the posterior wall of the orbit (fig. 1). It is covered by a thick temporal fascia from which, in some specimens, some of the most superficial fibers appear to originate. The temporalis is usually described in three portions: anterior (TA), posterior (TP), and suprazygomatic (TZ).

The TA [lateral temporalis of Ball and Roth, 1995; Thorington and Darrow, 1996] originates from the temporalis fascia and the inferior temporal line behind the postorbital process. In M. monax, the TA is more distinct from the TP than it is in A. rufa. The fibers converge on the anterior edge of the coronoid process and insert via a short tendon.

The TP [medial temporalis of Ball and Roth, 1995, Thorington and Darrow, 1996] is the largest portion of the temporalis. It covers the entire skull between the inferior temporal line, the posterior wall of the orbit, the lateral edge of the squamous portion of the temporal bone, and the nuchal crest. It inserts on the medial and lateral sides of the coronoid proces and the tip of the process, via a stout tendinous continuation of the tip. The most lateral fibers of the temporalis originate from the zygomatic process of the temporal bone and are called the TZ. There is no clear anatomical plane separating the TZ and the TP. Nor is there a separation between the TZ and the ZM. Stark and Wehrli [1935] appear to have labeled fibers of the TZ part of the ZM in their study of M. marmota.

In A. rufa, the temporalis is the largest of the masticatory muscles. The TA originates from the inferior temporalline by a thin tendinous sheet, the fasciculi originating from the deep surface of the sheet. The fibers of the TA run anteriorly and ventrally to a tendinous insertion at the superior and anterior edge of the coronoid process. The TA is incompletely separable from the TP below it.

The TP is the largest portion of the temporalis in A. rufa. Its boundaries are the inferior temporal line, the nuchal crest, and the posterior wall of the orbit. It originates from the entire surface of the skull within these boundaries. Many of the fasciculi converge on a central tendon that is a tendinous continuation of the coronoid process, but the insertion of the muscle covers most of the medial and lateral surfaces of the coronoid process.

The TZ is defined as fibers of the temporalis that originate on the dorsal surface of the zygomatic process of the temporal bone. In A. rufa the fibers of the TZ cannot be separated from the most lateral fibers of the TP, nor can they be separated from the most posterior fibers of the $\mathrm{ZM}$. The fibers of the TZ run anteriorly and ventrally to insert on the lateral surface of the coronoid process, near its base.

\section{Internal Pterygoid}

The internal pterygoid (PI) of M. monax is a complex muscle that fills the space on the medial side of the mandibular ramus. It originates in the pterygoid fossa between the medial and lateral pterygoid plates, and on the lateral wall of the medial plate itself. A thick tendon of origin runs ventrally from the edge of the lateral pterygoid plate, and most of the medial and posterior surface of the PI is covered by a thin aponeurosis that attaches to the angle of the mandible and serves as a broad tendon of insertion. Although on the surface the PI appears to be a fairly simple muscle it is, in reality, quite complex. At its medial end, numerous thin tendons of origin run vertically through the muscle mass, so that the fasciculi are far shorter than the distance from the origin to the insertion of the entire muscle.

The PI in A. rufa is just as complex as it is in M. monax. Most of the origin is fleshy, but a dense, flat tendon originates at the lateral edge of the fossa and covers much of the dorso-lateral surface of the muscle. Laterally, in the area of the muscle that is covered by the superior wall of the pontoon, fasciculi originate from this dorsal tendon. These fasciculi insert on the internal surface of the mandible between the angle and the lateral end of the pontoon (fig. 3).

\section{Muscle Weights}

Wet muscle weights for seven jaw adductor muscles from one side of the head are presented in table 2 . The greatest variation in size occurs in the temporalis of A. rufa, which accounts for a mean of $34 \%$ of the total adductor mass ( $\mathrm{n}=4$, range 30.3-37.9).

The major anatomical difference between protrogomorphs and sciuromorphs is that the relative size the ALM is much greater in sciuromorphs than in protrogomorphs. In A. rufa the ALM is only $6 \%$ of the total adductor mass $(\mathrm{n}=4$, SD 2).

\section{Bizygomatic Breadth}

The lateral end of the pontoon or bulge is the masseteric line; it marks the separation of the attachment areas of the PLM and the SM (fig. 4). The lateral edge of the zygomatic arch is dorsal and slightly lateral to the lateral edge of the mandible. In species that have relatively wide skulls, the size of the mandibular bulge is large, the larg- 
Fig. 4. Posterior views of the right mandibles in A. rufa and M. monax. Tracings from photographic prints. Attachment areas for the SM, PLM, and PI are indicated. Arrows indicate the most lateral points on each mandible, which is the most lateral point on the 'pontoon' (or apophysis) in Aplodontia and the masseteric line in Marmota.

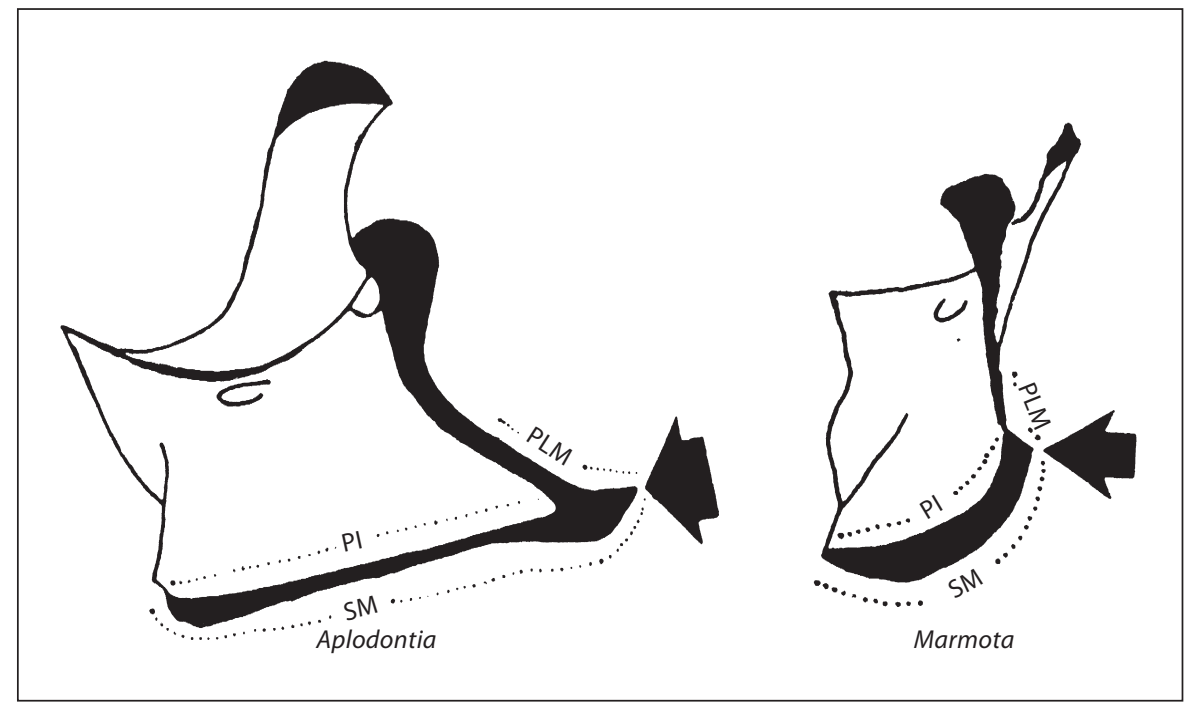

Table 2. Adductor muscle masses

\begin{tabular}{|c|c|c|c|c|c|c|c|}
\hline \multirow[t]{2}{*}{ Species } & \multicolumn{7}{|c|}{ Muscle } \\
\hline & SM & ALM & PLM & $\mathrm{ZM}$ & $\mathrm{PM}$ & $\mathrm{T}$ & PI \\
\hline \multicolumn{8}{|c|}{ M. $\operatorname{monax}(\mathrm{n}=2)$} \\
\hline Means, $g$ & 7.24 & 4.44 & 5.68 & 1.27 & 0.21 & 9.20 & 2.82 \\
\hline $\mathrm{SD}, \mathrm{g}$ & 1.14 & 1.57 & 2.57 & 0.24 & 0.21 & 3.04 & 1.62 \\
\hline Means, \% & 24 & 14 & 18 & 4 & 1 & 30 & 9 \\
\hline $\mathrm{SD}, \%$ & 3 & 1 & 3 & 1 & 1 & 1 & 1 \\
\hline \multicolumn{8}{|c|}{ A. $r u f a(\mathrm{n}=4)$} \\
\hline Means, $g$ & 1.78 & 0.60 & 2.67 & 0.92 & 0.23 & 3.64 & 0.84 \\
\hline $\mathrm{SD}, \mathrm{g}$ & 0.20 & 0.19 & 0.61 & 0.18 & 0.09 & 0.83 & 0.11 \\
\hline Means, \% & 17 & 6 & 25 & 9 & 2 & 34 & 8 \\
\hline $\mathrm{SD}, \%$ & 1 & 2 & 2 & 2 & 1 & 4 & 2 \\
\hline \multicolumn{8}{|c|}{ T. thomomys } \\
\hline Means, g & 0.08 & 0.34 & 0.11 & 0.02 & 0.02 & 0.20 & 0.04 \\
\hline Means, \% & 10 & 42 & 14 & 2 & 2 & 25 & 5 \\
\hline \multicolumn{8}{|l|}{ R. affinis } \\
\hline Means, $g$ & 1.41 & 1.55 & 1.06 & 0.04 & 0.04 & 1.69 & 0.61 \\
\hline Means, \% & 22 & 24 & 17 & 1 & 1 & 26 & 10 \\
\hline \multicolumn{8}{|c|}{ S. variagatoides } \\
\hline Means, $g$ & 0.04 & 0.06 & 0.05 & 0.01 & 0.01 & 0.06 & 0.03 \\
\hline Means, \% & 15 & 23 & 19 & 4 & 4 & 23 & 12 \\
\hline \multicolumn{8}{|l|}{ T. eutamias } \\
\hline Means, g & 0.08 & 0.08 & 0.05 & 0.03 & 0.01 & 0.08 & 0.04 \\
\hline Means, $\%$ & 22 & 22 & 14 & 8 & 3 & 22 & 11 \\
\hline \multicolumn{8}{|l|}{ C. cynomys } \\
\hline Means, g & 1.92 & 0.90 & 0.73 & 0.25 & 0.16 & 1.53 & 0.72 \\
\hline Means, \% & 31 & 14 & 12 & 4 & 3 & 25 & 12 \\
\hline
\end{tabular}

Functional Anatomy of Incisal Biting Part 1: Anatomy and Life History est bulge being the pontoon of $A$. rufa (fig. 5). Even in tree squirrels such as Ratufa and Sciurus there is a slight lateral bulge in the mandibular ramus which corresponds to the pontoon in A. rufa. There is a significant positive correlation between bizygomatic width and width of the mandibular bulge (measured as width of the mandibular angle at its posterior end $)(\mathrm{r}=0.89, \mathrm{p}<0.001, \mathrm{n}=21)$. There is also a significant positive correlation between skull height and mandibular height $(\mathrm{r}=0.94, \mathrm{p}<0.001$, $\mathrm{n}=21$; fig. 6). Tree squirrels have tall and narrow skulls, and tall and narrow mandibles. A. rufa has a short and wide skull, and a short and wide mandible. Terrestrial sciuromorphs are intermediate.

\section{Discussion}

The mandibular region of $A$. rufa is distinct from that of other extant rodents. The caudal ends of the mandibular rami have large apophyses (pontoons) that project laterally so that the mandibular condyles and coronoid processes are far medial to the most lateral points on the ramus. At first glance, homologies between the anatomical features of the mandible in A. rufa and other rodents are obscure. But if the osseus anatomy is considered along with the jaw musculature, it can be seen that the peculiar features of $A$. rufa are best described simply as 'exaggerations' of features found in other species. Similarities among the species are most apparent when mandibles are viewed from the rear. 
Wide, flat skulls are found in burrowing, fossorial rodents [Stein, 2000]. This association between skull shape and fossorial life history has been reported in many mammalian groups [Hildebrand, 1985], as well as extant [Gans, 1960] and fossil amphibians [Wilson, 1941; Bellairs, 1950; Bolt and Wassersug, 1975]. Samuels and van Valkenburgh [2009, p. 262] demonstrated that 'rodents with similar digging habits show broad-scale convergence in skull shape'.

The evolution of a lateral bulge in the mandible permits certain anatomical relationships to remain fairly constant among the species. In transverse (coronal) section, the most lateral fibers of the PLM are nearly vertical in all protrogomorph/sciuromorph species dissected. In animals with wide skulls, if there were no bulge the insertion on the mandible would be medial to the zygomatic arch and these fibers of the PLM would produce a strong laterally directed component of force. The most medial fibers of the PI are also nearly vertical in each of the species, since the medial edge of the angle is inferior and just slightly lateral to the medial pterygoid plate. If the ventral edge of the angle did not remain in its position inferior to the medial pterygoid plate, migrating laterally in relatively wide skulls, the PI would have a much stronger medial component of force since there would be no vertical fibers in the medial portion of the muscle. And the relative size of the PI would be quite small since there would be no horizontal plate of bone for the insertion of the PI. The relative size of the SM would also be small since it, too, inserts on the horizontal plate of bone between the lateral edge of the pontoon (or lateral bulge) and the medial edge of the angle. Thus, the presence of a lateral bulge limits the amount of mediolaterally directed forces in the PLM and PI, and maintains large areas for the insertions of the PI and SM.

Some features of the temporalis-ZM complex also appear to be related to widening of the skull and mandible. In species with relatively flat skulls, such as $A$. rufa and M. monax, there is a distinct postorbital constriction and the left and right temporal masses meet or nearly meet at the midline. Tree squirrels have vaulted, narrow skulls. In these species, there is very little postorbital constriction and the attachment of the temporalis muscle is confined to the lateral part of the skull roof, so that there is a wide, open area between the left and right temporal lines. In species with the relatively widest skulls, the temporalis and ZM comprise the greatest percentages of the total adductor mass (table 2). Conversely, species that have the tallest and narrowest skulls have the relatively smallest temporalis and ZM. In this respect, rodents are similar to

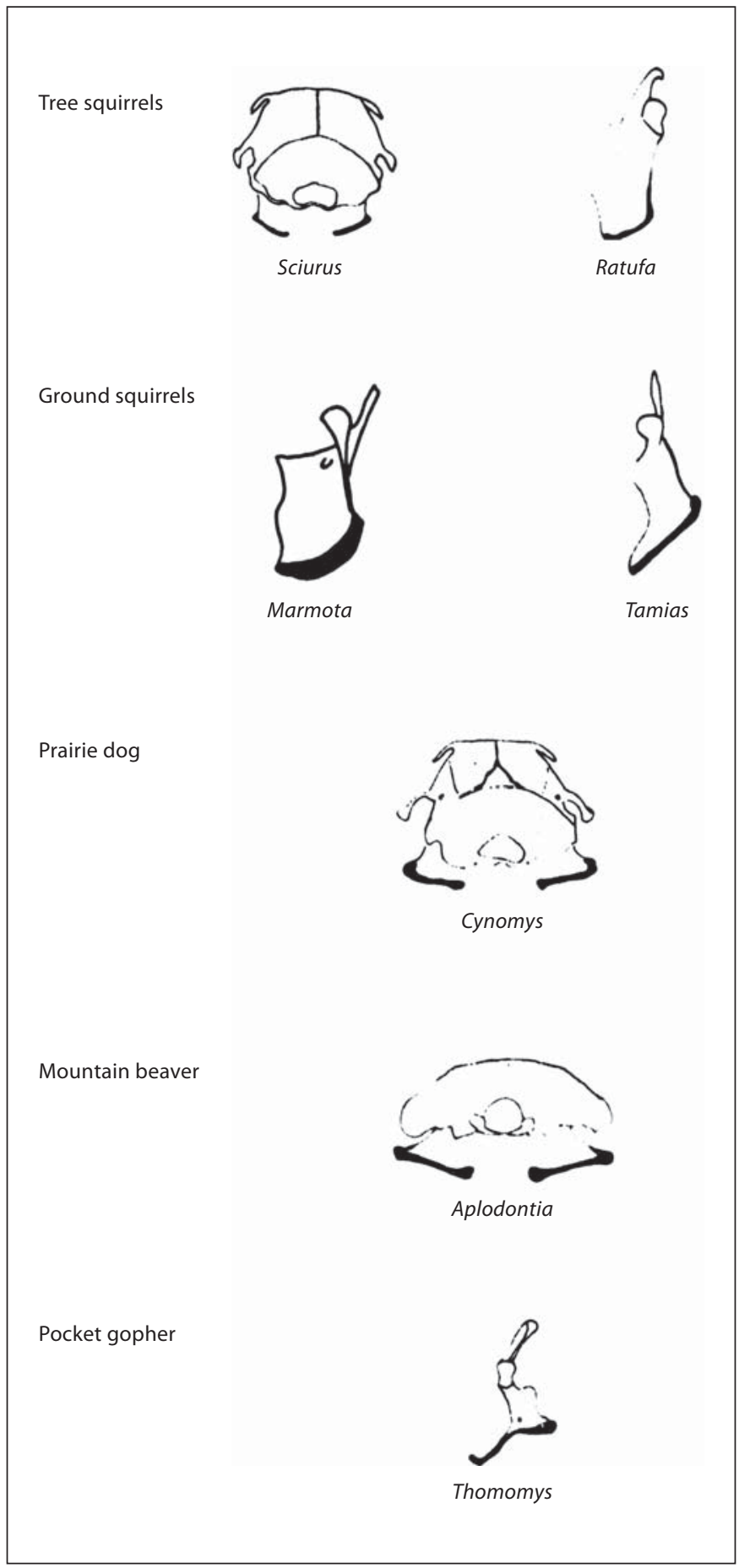

Fig. 5. Posterior views of skulls and mandibles. Tracings from photographic prints. The mandibles depicted are right mandibles. In species that have relatively wide skulls, the size of the mandibular bulge is large, the largest bulge being the apophysis of A. rufa. 
Fig. 6. Graph of skull breadth/height versus mandible breadth/height in the seven species considered in the mechanical analysis. The line drawings are of, from left to right, Sciurus variagatoides (S), Cynomys ludovicianus (C) and A. rufa (A) ( $\mathrm{n}=21$, $\mathrm{r}=0.71, \mathrm{p}<0.001) . \mathrm{E}=$ Tamias (Eutamias) sp.; $\mathrm{M}=$ M. monax $; \mathrm{R}=$ Ratufa affinis $; \mathrm{T}=$ Thomomys talpoides.

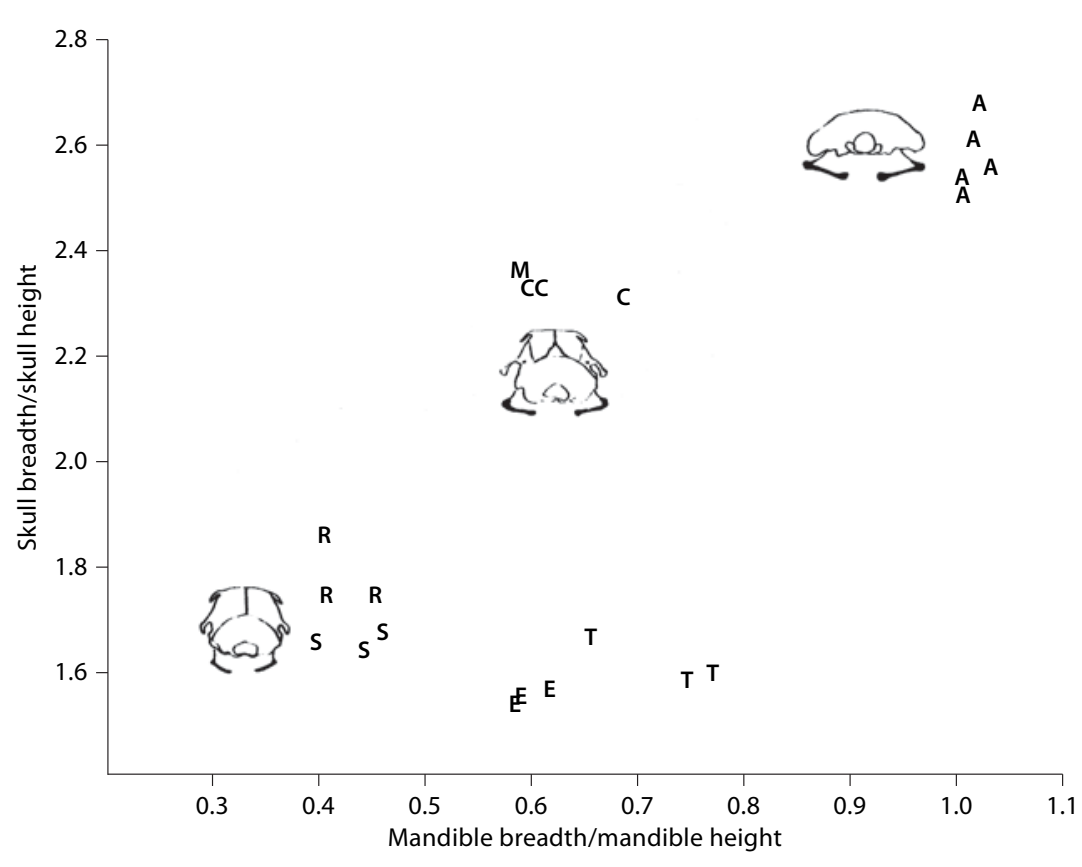

other mammals. In his multivariate statistical analyses of cranial shape in Equidae and Carnivora, Radinsky [1981a, b, 1984a, b] used temporal fossa width (which he defined as bizygomatic breadth minus breadth at the postorbital constriction) as a measure of temporalis size. Rodents with wide, flat skulls have relatively large temporalis muscles.

In general, species with tall and narrow skulls have tall and narrow posterior mandibles, and species with short and wide skulls have short and wide posterior mandibles (fig. 5, 6). Two of the studied species, however, are exceptions. Both Tamias and Thomomys (pocket gopher) have vaulted skulls similar to squirrels, but short and wide posterior mandibles.

Tamias (chipmunk) is a terrestrial, scratch-digging, rodent [Tamias striatus, Wishner, 1982] with large cheek pouches. Ball and Roth [1995] argued that the relatively large (even for rodents) diastemata of Tamias are related to the functions of the cheek pouches. It is also possible that the relatively wide posterior mandibular region is also part of the cheek pouch mechanism. Ball and Roth [1995, p. 289] also suggested that the Tamias 'sacrifices force at the incisors' in the position of the temporalis muscles but in the present results Tamias is similar to all of the other sciuromorphs in all measures of mechanical ability and is even the most 'efficient' for some.

Functional Anatomy of Incisal Biting Part 1: Anatomy and Life History
Thomomys is a pocket gopher and is categorized as a scratch digger and a chisel-tooth digger [Stein, 2000; Samuels and van Valkenburgh, 2009]. In a recent morphometric analysis of cranial/dental morphology in digging rodents, Thomomys falls within the range of the chisel tooth diggers [Samuels and van Valkenburgh, 2009]. Interestingly, in the same study, Aplodontia falls within the range of head-lift diggers in some of the analyses, and the authors note that the overall, triangular shape of the skull is similar to head-lift diggers. Although it is not certain that Aplodontia is a head-lift digger [Hopkins, 2005] in the wild, I have observed caged individuals pushing material with their heads.

Historically, rodents are characterized as having a relatively small temporalis muscle in comparison with other mammals [Turnbull, 1970; Novacek, 1986]. A relatively small temporalis may insure that, even in powerful biting, almost all of the bite force is projected along the long axis of the lower incisor since regulation of the force produced by even a small temporalis muscle can produce significant changes in the direction of the bite force.

The monophyly of the aplodontoid-sciuroid clade is highly corroborated. Derived features of the cranial foramina [Wahlert, 1985] and the bony architecture of the middle ear [Parent, 1983; Lavocat and Parent, 1985], as well as albumin cross-reactions [Sarich, 1985], support 
the clade. Aplodontoids and sciuroids are distinguished from one another on the basis of only a very few characters. It is easy to differentiate the modern aplodontoid A. rufa from M. monax and other sciuroids on the basis of the enlarged, sciuromorphous ALM alone. But when one examines the fossil records of these groups, the differences are not so apparent. Protosciurus [Black, 1961; Wood, 1965; Emry and Thorington, 1982; Korth, 1987; but cf., Vianey-Liaud, 1985] is an Oligocene rodent that was protrogomorphous, having no extension of the ALM in front of the zygomatic arch, but also sharing derived features of the teeth, cranial skeleton, and postcranial skeleton with sciurids. Vianey-Liaud [1985, p. 283] disagrees, suggesting that 'it is no longer possible to distinguish an archaic sciurid from an aplodontid'. However, two other fossil sciurids also appear to be 'protrogomorphous'.

1. Oligospermophilus [Korth, 1987], and Cedromus [Korth and Emry, 1991] are fossil sciurids that exhibit a 'unique zygomatic structure' [Korth and Emry, 1991]. In these genera, the attachment site of the ALM is largely confined to the ventral zygomatic arch (the protrogomorphous condition), but the anterior end of the arch is slightly 'upturned', so that the attachment area appears to spread anteriorly in front of the arch (the sciuromorphous condition). Examination of numerous skulls of $A$. rufa from the collections of the Field Museum of Natural History and the American Museum of Natural History reveals individuals in which the area for the origin of the ALM spreads onto the anterior surface of the zygomatic arch (fig. 7). Similar variations have been described in other fossil rodents. Variations in the origin of the ALM of some fossil gliroids are described by Vianey-Liaud [1985], which led her to argue that expansion of the ALM occurred independently in muroids and gliroids. (Thus, 'myomorphy' was achieved independently in muroids and gliroids.) Wood $[1962,1965]$ describes expansions of the ALM in ischyromyid fossils which he terms 'incipient sciuromorphy.' It is unclear whether the structure of the attachment site of the ALM in Oligospermophilus and Cedromus fall within the range of variation seen in Aplodontia. If so, then these genera are clearly protrogomorphous sciurids. If not, then the condition of the anterior zygomatic arch in Oligospermophilus and Cedromus may represent the 'incipient sciuromorphy' that led to the true sciuromorphous condition seen in sciurids. In any case, these variations in the attachment areas of the ALM demonstrate that there are numerous species which do not fit neatly into the morphological categories called 'sciuromorphy' and 'protrogomorphy.'

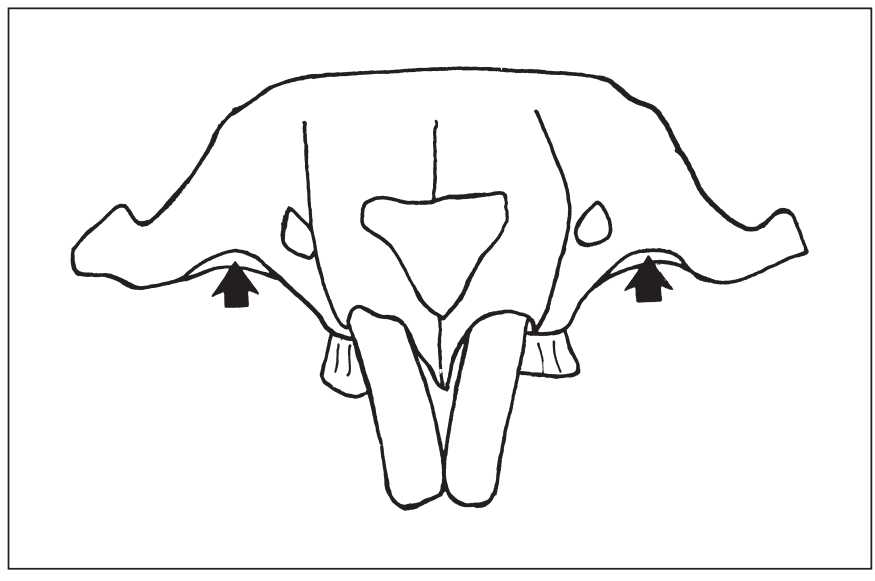

Fig. 7. Incipient sciuromorphy in A. rufa californicus (AMNH 1297). Tracing from a photograph. Arrows point to areas on the anterior surface of the zygomatic arch for the attachment of the ALM.

There is more than one kind of sciuromorphy. Comparisons of the attachment sites for the origins of the ALM and PLM in a wide variety of rodents support the conclusion that the attachments in A. rufa and sciurids are different from those of other rodents. In Aplodontia and in all sciurids examined, a distinct bony ridge marks the attachment of the tendinous aponeurosis which separates the ALM and PLM. In Thomomys, and other geomyid and murine rodents, there is no distinct ridge for a strong aponeurosis separating anterior and posterior portions of the muscle. In addition, the attachment of the ALM spreads posteriorly along the ventral surface of the zygomatic arch, medial to the pars posterior. Thus, 'sciuromorphy' in geomyids and murines is not homologous to the sciuromorphy of the aplodontoid/sciuroid clade.

The morphology of the ventroanterior region of the arch in the glirids also appears to be similar to that seen in the Eocene rodent Sciuravus nitidus [Dawson, 1961]. Although the anterior arch broadens posteriorly, the ventral edge of the arch is strikingly similar to the same region in the dipodids. Sciuravids are thought to be most closely related to geomyids and murids [Wood, 1937; Dawson, 1961, 1977]. Among the extant species, when the percentage of total adductor mass represented by the ALM is compared in sciuromorphous species, Thomomys is distinct. The ALM of Thomomys comprises $42 \%$ of the total adductor mass, a much greater percentage than that found in any of the sciuroids. The largest percentage found in any of the sciurids is in Ratufa, in which the ALM comprises $24 \%$ of the total adductor mass. The smallest per- 
centage (mean 6\%, SD 2) is found in A. rufa. In Thomomys, the ALM is three times the mass of the PLM. Clearly, the masseter complex of the geomyid Thomomys is different from that of $A$. rufa and the sciurids.

Numerous early rodents from the Eocene and the Oligocene [Wood, 1962, 1973, 1975; Korth, 1984] have been described as 'incipiently hystricognathous,' in part because of the presence of a fossa on the lateral side of the mandible ventral to the condyle, presumably for the insertion of a muscle which was said to be found only in hystricognathous rodents, the $\mathrm{m}$. lateralis profundus, pars posterior, deep division [Woods, 1972] or m. masseter posterior [Woods and Howland, 1979]. A similar (if not homologous) PM and corresponding fossa is present in A. rufa and sciurids (and even the geomyid Thomo$m y s)$. Therefore, the presence of a fossa ventral to the mandibular condyle is not an indication of 'incipient hystricognathy' nor does it represent a synapomorphy of these early rodents and hystricognathous rodents.

A. $r u f a$ is a member of the aplodontoid-sciuroid clade with a wide and flat skull. The large temporalis and mandibular apophyses of $A$. rufa are features related to its relatively wide skull. Such features are found in less dramatic forms in other sciuromorphous species and the basic arrangement of the masticatory muscles of $A$. rufa is similar to the arrangement seen in sciuromorphs.

\section{Acknowledgements}

The beautiful drawings of $A$. rufa and M. monax in figures $1-4$ are the works of Sharon Hewitt (www.articulategraphics. com). I would like to thank all of the many individuals who helped me in the course of this research. In particular, I would like to acknowledge the help of Walter Greaves, Sue Herring, the late Jim Fuller, and all of the other past and present members of the Departments of Oral Anatomy and Anatomy (now Oral Biology), University of Illinois at Chicago, Ill.; Dean Dessem, Keith Condon, Rebecca German, and other fellow graduate students and postdocs; Bruce Patterson and other members of the staff of the Field Museum of Natural History; Guy Musser, John Wahlert, and other members of the staff of the American Museum of Natural History; David DeCalesta and Gary Witmar at Oregon State University; John Yunger at Governors State University. Special thanks to W.D. Carlock. This work would not have been possible without years of support from Renée, Rachael, and Leah. Thanks to L. Gallo and one anonymous reviewer for constructive comments. This study was supported in part by grants from Sigma Xi, the National Institute for Dental Research (R03 DE06279), and the University of Illinois at Chicago.

\section{References}

Adkins, R.M., E.L. Gelke, D. Rowe, R.L. Honeycutt (2001) Molecular phylogeny and divergence time estimates for major rodent groups: evidence from multiple genes. Mol Biol Evol 18: 777-791.

Adkins, R.M., A.H. Walton, R.L. Honeycutt (2003) Higher-level systematics of rodents and divergence time estimates based on two congruent nuclear genes. Mol Phylogenet Evol 26: 409-420.

Anderson, S., J.K. Jones, Jr. (1984) Orders and Families of Recent Mammals of the World. New York, Wiley.

Ball, S.S., V.L. Roth (1995) Jaw muscles of New World squirrels. J Morphol 224: 265-291.

Becht, G. (1953) Comparative biologic-anatomical researches on mastication in some mammals. Proc Kon Ned Akad Wet, Ser C 56 : 508-527.

Bellairs, A. d'A. (1950) Observations on the cranial anatomy of Anniella, and a comparison with that of other burrowing lizards. Zool Soc Lond Proc 119: 887-904.

Black, C.C. (1961) Rodents and lagomorphs from the Miocene Fort Logan and Deep River formations of Montana. Postilla 48: 1-20.

Bolt, J.R., R.J. Wassersug (1975) Functional morphology of the skull in Lysorophus: a snakelike Paleozoic amphibian (Lepospondyli). Paleobiology 1: 320-332.
Brandt, J.F. (1855) Beiträge zur näheren Kenntniss der Säugethiere Russlands. Mém Acad Imp Sci St-Pétersbourg, Sér 6 9: 1-365.

Coues, E. (1877) Haplodontidae. Monographs of North American Rodentia. United States Geographical Survey of the Territories, Report 11, pp 543-601.

Dawson, M.R. (1961) The skull of Sciuravus nitidus, a middle Eocene rodent. Postilla 53: 113.

Dawson, M.R. (1977) Late Eocene rodent radiations: North America, Europe and Asia. Geobios Mémoire Spécial 1: 195-209.

Debry, R. W., R. M. Sagel (2001). Phylogeny of Rodentia (Mammalia) inferred from the nuclear-encoded gene IRBP. Mol Phylogenet Evol19: 290-301.

Druzinsky, R.E. (1989) Incisal biting in Aplodontia rufa and Marmota monax; Ph D thesis, University of Illinois, Chicago. Ann Arbor, University Microfilms International.

Druzinsky, R.E. (1995) Incisal biting in the mountain beaver (Aplodontia rufa) and woodchuck (Marmota monax). J Morphol 226: 79-101.

DuBrul, E.L. (1980) Sicher's Oral Anatomy, ed 7. St Louis, Mosby.

Eastman, C.B. (1982) Hystricomorphy as the primitive condition of the rodent masticatory apparatus. Evol Theor 6: 163-165.
Emry, R.J., R.W. Thorington (1982) Descriptive and comparative osteology of the oldest fossil squirrel, Protosciurus. Smithsonian Contrib Paleobiol 67: 1-14.

Fish, D.R. (1983) Aspects of masticatory form and function in common tree shrews, Tupaia glis. J Morphol 176: 15-29.

Gans, C. (1960) Studies on amphisbaenids (Amphisbaenia, Reptilia). I. A taxonomic revision of the Trogonophinae, and a functional interpretation of the amphisbaenid adaptive pattern. J Am Mus Nat Hist. Bull 119: 131204

Hartenberger, J.-L. (1985) The Order Rodentia: major questions on their evolutionary origin, relationships and suprafamilial systematics; in Luckett, E.W.P., E.J-L. Hartenberger (eds): Evolutionary Relationships among Rodents: A Multidisciplinary Analysis. New York, Plenum Press, NATO ASI Series, Ser A: Life Sciences, vol 92, pp 1-33.

Hopkins, S. S. B. (2005) The evolution of fossoriality and the adaptive role of horns in the Mylagaulidae (Mammalia: Rodentia). Proc R Soc B 272: 1705-1713.

Huchon, D., F.M. Catzeflis, E.J.P. Douzery (1999). Molecular evolution of the nuclear von Willebrand factor gene in mammals and the phylogeny of rodents. Mol Biol Evol 16: 577-589. 
Huchon, D., F.M. Catzeflis, E.J.P. Douzery (2000) Variance of molecular datings, evolution of rodents, and the phylogenetic affinities between Ctenodactylidae and Hystricognathi. Proc R Soc B 267: 393-402.

Huchon, D., O. Madsen, M. Sibbald, K. Ament, M.J. Stanhope, F. Catzeflis, W.W. de Jong, E.J.P. Douzery (2002) Rodent phylogeny and a timescale for the evolution of glires: evidence from an extensive taxon sampling using three nuclear genes. Mol Biol Evol 19: 1053-1065.

Klingener, D. (1970) Superficial facial musculature of Aplodontia. J Mammal 51: 35-41.

Korth, W.W. (1984) Earliest Tertiary evolution and radiation of rodents in North America. Bull Carnegie Mus Nat Hist 24: 1-71.

Korth, W.W. (1987) New rodents (Mammalia) from the Late Barstovian (Miocene) Valentine Formation, Nebraska. J Paleontol 61: 1058-1064.

Korth, W.W., Emry, R.J. (1991) The skull of Cedromus and a review of the Cedromurinae (Rodentia, Sciuridae). J Paleontol 65: 984-994.

Landry, S.O., Jr. (1957) The interrelationships of the New and Old World hystricomorph rodents. Univ Calif Publ Zool 56: 1-118.

Landry, S.O. (1999) A proposal for a new classification and nomenclature for the Glires (Lagomorpha and Rodentia). Mitt Mus Natkd Berl Zool Reihe 75: 283-316.

Lavocat, R. (1974) What is an hystricomorph?; in Rowlands, I.W., B.J. Weir (eds): The Biology of the Hystricomorph Rodents. Symp Zool Soc Lond, vol 34, pp 7-20.

Lavocat, R., J-P. Parent (1985) Phylogenetic analysis of middle ear features in fossil and living rodents; in Luckett, E.W.P., E.J-L. Hartenberger (eds): Evolutionary Relationships among Rodents: A Multidisciplinary Analysis. New York, Plenum Press, NATO ASI Series, Seri A: Life Sciences, vol 92, pp 333-354.

Linnaeus, C. (1758) Systema Naturae, ed 10. Laurenti Salvi, Stockholm.

Luckett, W.P., J.-L. Hartenberger (1985) Evolutionary relationships among rodents: comments and conclusions; in Luckett, E.W.P., E.J-L. Hartenberger (eds): Evolutionary Relationships among Rodents: A Multidisciplinary Analysis. New York, Plenum Press, NATO ASI Series, Ser A: Life Sciences, vol 92, pp 685-712.

Meng, J. (1990) The auditory region of Reithroparamys delicatissimus (Mammalia, Rodentia) and its systematic implications. Am Mus Novit 2972: 1-35.

Meng J, Y. Hu, C.K. Li CK (2003) The osteology of Rhombomylus (Mammalia: Glires): implications for phylogeny and evolution of Glires. Bull Am Mus Nat Hist 275: 1-247.

Nedbal, M.A., R.L. Honeycutt, D.A. Schlitter. (1996) Higher-level systematics of rodents (Mammalia: Rodentia): Evidence from the mitochondrial 12 S rRNA gene. J Mamm Evol 3: 201- 237.
Novacek, M.J. (1986) The skull of leptictid insectivorans and the higher-level classification of eutherian mammals. J Bull Am Mus Nat Hist 183: $1-112$.

Offermans M, F. De Vree (1990) Mastication in springhares, Pedetes capensis, a cineradiographic study. J Morphol 205: 53-67.

Parent, J-P. (1983) Anatomie et valeur systématique de l'oreille moyenne des rongeurs actuels et fossiles. Mammalia 47: 93-122.

Parsons, F.G. (1894) On the myology of the sciuromorphine and hystricomorphine rodents. Proc Zool Soc Lond 18: 251-297.

Radinsky, L. (1981a) Evolution of skull shape in carnivores. 1. Representative modern carnivores. J Biol J Linn Soc 15: 369-388.

Radinsky, L. (1981b) Evolution of skull shape in carnivores. 2. Additional modern carnivores. J Biol J Linn Soc 16: 337-355.

Radinsky, L. (1984a) Basicranial axis length ' $v$ ' skull length in analysis of carnivore skull shape. J Biol J Linn Soc 22: 31-41.

Radinsky, L. (1984b) Ontogeny and phylogeny in horse skull evolution. J Evol 38: 1-15.

Samuels, J.X., B. van Valkenburgh (2009) Craniodental adaptations for digging in extinct burrowing beavers. J Vert Paleontol 29: 254268.

Sarich, V.M. (1985) Rodent macromolecular systematics; in Luckett, E.W.P., E.J-L. Hartenberger (eds): Evolutionary Relationships among Rodents: A Multidisciplinary Analysis. New York, Plenum Press, NATO ASI Series, Ser A: Life Sciences, vol 92, pp 423-452.

Satoh, K., F. Iwaku (2004) Internal architecture, origin-insertion site, and mass of jaw muscles in Old World hamsters. J Morphol 260: 101-116.

Satoh, K., F. Iwaku (2006) Jaw muscle functional anatomy in northern grasshopper mouse, Onychomys leucogaster, a carnivorous murid. J Morphol 267: 987-999.

Satoh, K., F. Iwaku (2008) Masticatory muscle architecture in a murine murid, Rattus rat$t u s$, and its functional significance. Mamm Study 33: 35-42

Schumacher G.H. (1961) Funktionelle Morphologie der Kaumuskulatur. Jena: VEB Gustav Fischer Verlag.

Simpson, G.G. (1945) The principles of classification and a classification of mammals. Bull Am Mus Nat Hist 85: 1-350.

Stark, D., H. Wehrli (1935) Die Kaumuskulatur von Marmota marmota L. Z Säugetierkd 10: 33-38.

Stein, R. B. (2000) Morphology of subterranean rodents; in Lacey, E.A., J. L. Patton, G. N. Cameron (eds): Life Underground: The Biology of Subterranean Rodents. Chicago, University of Chicago Press, pp 19-61.

Thorington, R.W., Jr., K. Darrow (1996) Jaw muscles of Old World squirrels. J Morphol 230: 145-165.
Tullberg, T. (1899) Über das System der Nagethiere, eine phylogenetische Studie. Nova Acta Reg Soc Sci Upsala, Ser 3, 18: 1-514.

Turnbull, W.D. (1970) Mammalian masticatory apparatus. Fieldiana Geol 18: 149-356.

Vianey-Liaud, M. (1985) Possible evolutionary relationships among Eocene and Lower Oligocene rodents of Asia, Europe, and North America; in Luckett, E.W.P., E.J-L. Hartenberger (eds): Evolutionary Relationships among Rodents: A Multidisciplinary Analysis. New York, Plenum Press, NATO ASI Series, Seri A, Life Sciences, vol 92, pp 277-310.

Von Toldt, C. (1905) Der Winkelforsatz des Unterkiefers beim Menschen und bei den Säugetieren und die Beziehungen der Kaumuskeln zu demselben. 2. Teil. Sitzungsber Kaiserl Akad Wiss Wien Mathem-Naturw 114: 315476.

Wahlert, J.H. (1985) Cranial foramina of rodents. In Luckett, E.W.P., E.J-L. Hartenberger (eds): Evolutionary Relationships Among Rodents: A Multidisciplinary Analysis. New York, Plenum Press, NATO ASI series, Series A, Life Sciences, vol 92, pp 311-332.

Wilson, J.A. (1941) An interpretation of the skull of 'Buettneria' with special reference to the cartilages and soft parts. Contrib Mus Paleont Univ Mich 6: 71-111.

Wishner, L. (1982). Eastern chipmunks: secrets of their solitary lives. Washington, Smithsonian Institution Press.

Wood, A.E. (1937) The mammalian fauna of the White River Oligocene. 2. Rodentia. Trans Am Phil Soc New Ser 28: 155-269.

Wood, A.E. (1955) A revised classification of the rodents. J Mammal 36: 165-187.

Wood, A.E. (1962) The Early Tertiary rodents of the family Paramyidae. Trans Amer Phil Soc New Ser 52: 11-261.

Wood, A.E. (1965) Grades and clades among rodents. Evolution 19: 115-130.

Wood, A.E. (1973) Eocene rodents, Pruett Formation, South West Texas; their pertinence to the origin of the South American Caviomorpha. Texas Meml Mus Pearce Sellards Ser 20: $1-40$

Wood, A.E. (1974) The evolution of Old World and New World hystricomorphs; in Rowlands, I. W., B.J. Weir (eds): The Biology of Hystricognath Rodents. London, Academic Press, Symp Zool Soc London, vol 34, pp. 21-60.

Wood, A.E. (1975) The problem of the hystricognathous rodents. Univ Mich Pap Paleontol 12: $75-80$.

Woods, C.A. (1972) Comparative myology of jaw, hyoid, and pectoral appendicular regions of New and Old World hystricomorph rodents. Bull Am Mus Nat Hist. 147: 115198

Woods, C.A., E.B. Howland (1979) Adaptive radiation of capromyid rodents: anatomy of the masticatory apparatus. J Mammal 60: $95-116$ 